\title{
E-SIMBIOZA - LEADING THE WAY TO A CIRCULAR ECONOMY THROUGH INDUSTRIAL SYMBIOSIS IN SLOVENIA
}

\author{
Urška Fric and Borut Rončević
}

Faculty of Information Studies in Novo mesto Ljubljanska cesta 31A, 8000 Novo mesto, Slovenia e-mail: urska.fric@fis.unm.si

\begin{abstract}
This paper provides a first insight into the level of understanding and implementation of industrial symbiosis (IS) in Slovenia. It is based on an online survey of a small sample of organizations actively involved in waste management. The results show that while their motivation to engage in IS include various environmental and economic benefits, as well as social responsibility, the concept and practice of IS is not well understood even within this group of organizations. Organizations that engage in IS would benefit from online tools enabling them to optimize their search for potential IS stakeholders with relevant types of waste materials for exchange. While the small sample size does not allow for generalizations, it provides evidence that an online platform to support IS can substantially contribute to a shift towards a circular economy. The article concludes with the presentation of one such successful initiative - e-Simbioza - as well as some guidelines for its future development.
\end{abstract}

Keywords: circular economy, industrial symbiosis, industrial symbiosis networks, e-platform, collaboration

\section{INTRODUCTION: STICKS AND CARROTS IN WASTE MANAGEMENT}

A vast majority of total waste in Slovenia is being produced in manufacturing and service economic activities, with municipal waste accounting for only $10 \%$ of the total waste production (SURS, 2017). As a result of positive economic trends, it is not surprising that the production of non-municipal waste in Slovenia has been increasing in the last three years. In 2016, almost 5.5 million tonnes of waste (hazardous and non-hazardous) was produced in Slovenia, which is approximately 5.45\% more than in 2015 (SURS, 2017). On a positive note, 4.4 million tonnes of waste - a $27 \%$ increase from 2015 - was processed (without filling and preparation for processing), and 138,000 tonnes of waste - a 50\% decrease from 2015 - was disposed of into landfills (SURS, 2017). However, in the same year, only $67 \%$ of waste collected was separated using municipal waste collection services, a 2\% decrease from 2015 (SURS, 2017). Furthermore, waste 
import decreased by nearly $4 \%$ from 2015 , while waste export increased by a staggering $40 \%$ (SURS, 2017), reducing the availability of potential secondary materials that could be used as an input to industrial production.

This implies not only that efforts to reduce negative environmental impact should primarily be focusing on non-municipal waste, but also that the current situation provides an abundance of opportunities for improved economic efficiency of production processes on the basis of reuse of secondary materials in the form of waste and by / products.

This business opportunity "carrot" goes hand in hand with the "stick" in the form of new and increasing demands by the European Union. Namely, one of the challenging goals of the $\mathrm{EU}$ is to reduce the volume of landfilled waste to $10 \%$ of its total production by 2030 , effectively requiring reuse of $90 \%$ of total waste. This approach to waste handling is also incorporated in the Directive on waste (2008/98/EC) which requires that all EU Member States adopt measures in the near future to allow for reuse of waste to the maximum extent possible (European Parliament and Council, 2008). Considering the alarming situation with respect to the low percentage of waste processing in Europe (only $44 \%$ of all waste being processed), in 2014 the European Commission published a proposal for new legislation on waste processing (European Commission, 2014) titled "Towards a circular economy: A zero waste programme for Europe". Implementation of the suggested changes should prioritize the path towards increasing the share of reuse by 2030 , i.e. increase reuse for municipal waste to $70 \%$ and packaging waste to $80 \%$, stop landfilling recyclable waste, and reduce the volume of food waste by $30 \%$ by 2025 (European Commission, 2014). The solution for achieving these extraordinarily ambitious goals is a paradigmatic shift towards a circular economy, where the waste - materials, waste water or energy - from one organization becomes input for another. This paradigm is a response to the pressures of growing consumption of the limited resources and environmental capacity and it is of one of the most developed waste handling concepts of modern time (Ellen MacArthur Foundation, 2017). Transitioning to a circular economy therefore focuses on reusing, rebuilding and recycling existing materials and products (Ellen MacArthur Foundation, 2017). It is based on using the energy from renewable sources, waiving the use of hazardous chemicals, reducing the consumption of raw materials, and influencing product design to allow circulation of materials and retaining added value for as long as possible in order to reduce waste production to zero (Ellen MacArthur Foundation, 2017). In a circular economy, products continue existing even after the materials or product itself comes to the end of its lifecycle (Ellen MacArthur Foundation, 2017). However, to achieve a paradigmatic shift to a circular economy, we need to implement changes along entire supply chains - from modifying product design and new business and marketing models to new methods of transforming waste into source and new consumer behavior types (European Commission, 2014:2). This implies a simultaneous comprehensive systemic change and technological innovations, but also innovations in organization, society, financial models and policy (European Commission, 2014:2). In EU Member States, which are compelled to reuse as much waste as possible as set out by the Directive on waste management 
(2008/98/EC), industrial symbiosis represents a relevant circular economy mechanism for transforming waste into sources. Industrial symbiosis characterizes simultaneous ecological, economic and social benefits from reusing waste and is understood as the relationship between three or more organizations involved in the exchange of secondary sources (Chertow, 2007) - materials, water and energy, comprised mostly of waste (Ehrenfeld and Gertler, 1997; Deutz, 2014; Boshkoska et al., 2018) - and where the exchange of sources represents cooperation between organizations (Chertow and Lombardi, 2005; Mirata and Emtairah, 2005; Lombardi and Laybourn, 2012; Domenech Aparisi, 2010; Rončević and Fric, 2015). In this relationship, every organization strives to gain benefits for itself, while at the same time adds to the benefits of society in general (Manahan, 1999). Such an industrial symbiosis relationship is exemplified by the following example from Slovenia. A wood-processing organization (A) sells wood chips, a by-product of its basic activity, to a cellulose producing organization (B) which uses them as raw material for the manufacture of paper. Organization A sells sawdust (also waste) to a gardening organization $(\mathrm{C})$ which uses it as mulch for protecting the soil. Industrial water, created in the cellulose manufacturing process and representing waste for organization $B$, is sold by organization $B$ to organization $C$ where it is first purified and then used for soil irrigation. All three organizations send mixed municipal waste to a heating plant (D) where it is first processed mechanically and biologically, fractioned and then used as a secondary source for the production of electricity and heat to be used by the general public (Fric, 2017).

Efficient handling of primary sources by re-using by-products and waste has become an increasing trend for organizations (in industrial and non-industrial sectors), which are following environmental policies within the EU and taking advantage of its ecological, economic and social benefits. This has already become a routine process for some EU member states, especially in the Netherlands, Germany, France and the UK. Numerous EU Member States - predominantly the most developed ones - offer one or several online platforms which facilitate supply and demand in waste to industrial and non-industrial organizations, thus creating industrial symbiosis networks. In Slovenia, however, the first instrument enabling industrial and non-industrial organizations to meet, exchange waste, save money and, as a "side effect", reduce the volume of landfilled waste, was only provided in 2017 (Faculty of Information Studies in Novo mesto, 2017) and our knowledge about the state of industrial symbiosis is very limited.1

In this article we present research on the attitudes of a small yet highly relevant sample of organizations engaging in industrial symbiosis in Slovenia. We first describe the research method, and then present the main results of the research. We conclude the article with a description of follow-up research activities resulting from proactive feedback

1 Before 2018 the only research on the topic was a small study "Inter-organizational trust and industrial symbiosis" focusing on the functioning of industrial symbiosis networks, supported by a grant by the Public Scholarship, Development, Disability and Maintenance Fund of the Republic of Slovenia. The project was financed by the Slovenian Ministry of Education, Science and Sport and the European Social Fund. 
and use of the e-Simbioza online platform and which are planned for implementation in the near future for the purpose of upgrading e-Simbioza.

\section{METHODOLOGY}

\subsection{Research questions and goals}

Taking into consideration the research problem and its relevance, we defined five questions to focus our research.

The first research question (RQ1) was: Are participating industrial and non-industrial organizations in Slovenia acquainted with industrial symbiosis? The primary intention of this research question was to learn what industrial symbiosis represents to organizations and whether their interpretation is anywhere close to Chertow's (2007) fundamental definition of industrial symbiosis, by which it represents the cooperation between three or more organizations involved in the exchange of secondary sources - materials, water or energy, mostly in the form of waste.

The second research question $(R Q 2)$ was: Does industrial symbiosis exist between industrial and non-industrial waste management organizations in Slovenia? Here we were interested in learning whether the organizations, which are acquainted with industrial symbiosis, actually take part in its implementation and, if yes, how industrial symbiosis functions. Furthermore, we were interested in implementation forms, such as selling and buying waste to be used as raw material, giving away waste, mutual exchange, etc. The third research question $(R Q 3)$ was: Which are the main reasons and obstacles for organizations to cooperate in industrial symbiosis? We wanted to find whether the main objective was the increasingly strict European environmental legislation, corporate social responsibility, or environmental, economic and social benefits of industrial symbiosis. The fourth research question (RQ4) was: Is industrial symbiosis implemented in the form of (informal) industrial symbiosis networks between three or more organizations? The answer to this question would tell us how many organizations are involved in industrial symbiosis, i.e. the size of individual industrial symbiosis networks, where participating organizations in our research sample act as members. Moreover, we were interested in the types of organizations which take part in industrial symbiosis networks: Are they business entities of different types, educational institutions, research institutions, public administration services, local communities, or the media?

The last research question $(R Q 5)$ was: Do waste management organizations feel that an online platform to simplify their search for potential partners in industrial symbiosis is need$e d$ ? With this question we aimed to ascertain whether organizations would choose to sell or buy waste as raw material through such online platform.

The first objective of the research ${ }^{2}$ was to identify all potential providers, intermediar-

2 The draft design for the e-Simbioza platform successfully applied the call for proposals "Projects involving industry and other activities on local and regional level - Creative path to knowledge 2016/2017" 
ies, and buyers of waste materials on the list of waste management entities provided by the Slovenian Environment Agency (ARSO) ${ }^{3}$. The second objective was to identify the existence of industrial symbiosis and the functioning of informal industrial symbiosis networks. The third objective also represented the core of the research - to design and implement a draft of the online platform named e-Simbioza which would allow providers, intermediaries and buyers of waste to meet and cooperate.

\subsection{Population and sample}

Our population consisted of organizations authorized for waste management in Slovenia. The list of authorized organizations is maintained by the Slovenian Environment Agency (ARSO) and is the only list of this type in Slovenia. We arranged the organizations into eight groups according to the type of waste handling they do (see Table 1) to harmonize the number of groups with the subject of research, i.e. organizations handling reusable waste, while organizations from other groups handle waste intended for incineration plants, waste disposal sites or other disposal facilities etc. Since the Agency's list does not contain any contact email addresses, we searched for the contact information through the Slovenian web business directory (Business directory bizi.si, 2017). Our intention was to find relevant persons who could supply as much high-quality information as possible, by focusing on the following sectors: ecology, waste management, quality, and R\&D. After extensive verification we were able to obtain valid contacts for a total of 2,174 organizations, which was our effective primary population. A total of 50 organizations from 10 statistical regions (out of 12) responded to our invitation to contribute data for our research. This provided us with a small sample that is not representative of the entrepreneurial population as a whole and it is strongly biased towards highly motivated organizations participating in industrial symbiosis. Therefore, we cannot generalize our conclusions to the population as a whole just on the basis of this sample. However, this sample is relevant from the perspective of an initial exploratory analysis and especially from the perspective of applied research intended to provide guidance on how to enhance implementation of an online platform to support industrial symbiosis and shift to a circular economy. Table 1 contains the number of organizations in groups before and after removing duplicate email addresses.

by the Public Scholarship, Development, Disability and Maintenance Fund of the Republic of Slovenia in cooperation with the Faculty for information studies Novo mesto, Komunala Novo mesto d.o.o., and the Society for development of voluntary services, i.e. their regional NGO center. The project lasted five months (from March to July 2017) and the e-Simbioza platform was financed by the Slovenian Ministry of Education, Science and Sport, Public Scholarship, Development, Disability and Maintenance Fund of the Republic of Slovenia, and the European Social Fund.

3 Waste management in Slovenia includes collection, transportation, processing and disposal of waste, including control of waste management. In the waste management sector, ARSO has the following functions: issue administrative acts based on waste management regulations; keep records for areas in which ARSO is obliged to keep records based on administrative acts and legal provisions on waste management; and maintain data on waste management (ARSO, 2017). 
Soc. ekol. Zagreb, Vol. 27 (2018.), No. 2

U. Fric and B.Rončević: E-Simbioza - Leading the Way to a Circular Economy... in Slovenia

Table 1. Selected groups of waste management organizations

\begin{tabular}{|l|c|c|}
\hline \multicolumn{1}{|c|}{$\begin{array}{c}\text { Waste management } \\
\text { organization group }\end{array}$} & $\begin{array}{c}\text { Number of organizations } \\
\text { in group before removing } \\
\text { duplicate email addresses }\end{array}$ & $\begin{array}{c}\text { Number of organizations } \\
\text { in group after removing } \\
\text { duplicate email addresses }\end{array}$ \\
\hline Waste processing organizations & 423 & 370 \\
\hline Waste disposal organizations & 34 & 27 \\
\hline Waste collection organizations & 140 & 139 \\
\hline $\begin{array}{l}\text { Waste management } \\
\text { intermediaries }\end{array}$ & 167 & 165 \\
\hline Waste transport organizations & 1211 & 12 \\
\hline Waste packaging & 12 & 169 \\
\hline Waste trading organizations & 174 & 12 \\
\hline $\begin{array}{l}\text { Independent facilities for } \\
\text { disassembling used vehicles } \\
\text { and associated collection points }\end{array}$ & 13 & 2085 \\
\hline Total & 2174 & \\
\hline
\end{tabular}

Invitations for participation in the online questionnaire were sent to 2,085 email addresses. For 380 emails we received bounced messages noting that the email address was either incorrect or no longer exists. After this, the primary sample was reduced to 1,705 organizations. In the end, the effective sample representing the foundation for analysis contained 50 organizations which participated in the study and covered 10 statistical regions according to the regional division of Slovenia (only the Zasavje and Gorizia regions were not represented).

Due to the limited timeframe for the entire project (five months), we decided to collect data using a web-based questionnaire as a research instrument. The other reason for selecting this instrument were financial capabilities, as financing had not been provided during the actual research phase (all logistical expenses related to the research were reimbursed only after the research / project was completed). Our goal first focused on collecting data using semi-structured interviews, however, our financial resources did not allow us to obtain the required responses from the 12 Slovenian regions. Because of the short timeframe we also had only five weeks for data collection. If the data collection phase had been longer, we could have ensured a substantially larger effective sample which might even have a representative value.

\subsection{Research instrument}

Since the research was relatively limited in time (five months), we performed data collection using an online questionnaire containing 23 questions: 19 were close-ended questions and four were open-ended questions. Questions were categorized into three 
sets. The first set of questions involved demographic data; the second set focused on how well the organizations know industrial symbiosis and whether they apply it; while the third set asked for their opinion on potential benefits of an online platform for taking part in industrial symbiosis. Out of the seven types of basic questions ${ }^{4}$ by Blaxter et al. (1996), we used five different types - number or information; categories; (multiple choice) lists; spreadsheets; and open-ended questions. An online questionnaire was created in 1KA open-source application for online surveys.

\subsection{Data collection}

The collection of quantitative and qualitative data took place over five weeks from April to May 2017. We began the data collection process by creating an email message in the form of a call for participation and sending the email using the free online application MailChimp to 2,085 email addresses. MailChimp allows sending free mass emails to a maximum 2,000 email addresses, but no more than 12,000 a month. This characteristic was one of the reasons we selected MailChimp, which also allowed us to manage the mass email campaigns and to create visually attractive email content. In the email invitation we described the purpose of our research to potential participants, focusing on the benefits the e-Simbioza online platform would mean for them, and invited them to participate in our online questionnaire. As a result of the first email campaign, we received 27 confirmations of participation and three refusals. We immediately replied to the organizations willing to participate, sending them links to the online questionnaire. After two weeks, we repeated the email campaign. The invitation to participate was sent to all email addresses, except to those which had previously confirmed their participation or refused it. After the second campaign, another 23 organizations agreed to participate. The other organizations did not reply to our email and did not directly refuse to participate. The average time to complete the online questionnaire was 10 minutes.

\subsection{Data processing}

After the data collection, we used IBM SPSS 23.0 and RStudio statistical software to manage and analyze the quantitative data obtained using a questionnaire with 19 closeended questions. First, we used univariate statistics to calculate frequency, percent, valid percent and cumulative percent for every variable (ordinal and nominal). In our search for responses to the research questions, we used Pearson's Chi-squared test and Fisher's exact test to verify if any two variables were associated. The reason for selecting these methods was mainly their versatility in analyzing descriptive variables, such as the ones we were dealing with. For managing and analyzing the qualitative data obtained using four open-ended questions, we used MAQDA 12 software. Since the answers were rela-

4 No scales and ranks were used. 
tively short, we skipped the editing and imported them in their original form directly into the software where they were coded into categories and concepts. The codes were then arranged into a hierarchy based on the questions.

\section{RESEARCH RESULTS}

\subsection{Demographics}

In the data collection phase we collected a total of 122 filled-out online questionnaires and logged 11 instances of the online questionnaire being opened, 56 instances of the cover note being opened, three completely empty questionnaires, and 50 usable questionnaires. It is important to note that 37 questionnaires were filled-out completely, while 13 questionnaires were only partially completed. This meant that the effective sample size was 50 units $(\mathrm{N}=50)$, i.e. organizations, most of which operate in the service industry (56\%), followed by the manufacturing industry (42\%), whereas only $2 \%$ operate in commercial trade. Only 10 out of the 12 Slovenian statistical regions were represented in the sample, with the Zasavje and Gorizia regions missing. The most represented statistical regions in descending order are Jugovzhodna Slovenija with 20\%, Osrednjeslovenska with $18 \%$, and Savinjska with $14 \%$. In terms of the size of the organizations, $23 \%$ of all responding organizations were large organizations, 38\% were medium-sized organizations, $23 \%$ small-sized organizations, and $17 \%$ of them were micro-organizations.

The largest number of respondents were limited liability organizations $(82 \%)$, followed by public limited organizations (12\%), institutes (4\%), and social enterprises $(2 \%)$. We found that $30 \%$ of the responding organizations operate on local, regional, national and international levels, whereas $54 \%$ of the organizations only operate on an international level, $26 \%$ on a national level, $28 \%$ on a regional level, and $22 \%$ on a local level.

\subsection{Level of understanding and implementing industrial symbiosis in Slovenia and organizations' needs regarding an online platform for industrial symbiosis}

Our first research question (RQ1) inquired whether the responding industrial and nonindustrial organizations in Slovenia are acquainted with the term industrial symbiosis. We were seeking to learn how organizations interpret the term and if their interpretation is even remotely similar to Chertow's original (2007) definition of industrial symbiosis. In this definition, industrial symbiosis represents the cooperation between three or more organizations involved in the exchange of secondary sources - raw material in the form of materials, water or energy - mostly consisting of waste.

The results of the question on the theoretical understanding of industrial symbiosis and its interpretation are shown in Table 2. A total of 48 out of 50 responding organizations answered this question. 
Soc. ekol. Zagreb, Vol. 27 (2018.), No. 2

U. Fric and B.Rončević: E-Simbioza - Leading the Way to a Circular Economy... in Slovenia

Table 2. Theoretical understanding of industrial symbiosis and its interpretation

\begin{tabular}{|c|c|c|c|c|c|}
\hline \multicolumn{5}{|c|}{$\begin{array}{c}\text { Are you acquainted with the term } \\
\text { industrial symbiosis? }\end{array}$} & \multirow[b]{2}{*}{$\begin{array}{l}\text { Interpretation of the term } \\
\text { industrial symbiosis }\end{array}$} \\
\hline 离 & 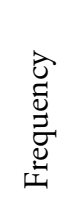 & 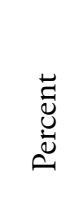 & $\frac{\overline{7}}{\stackrel{7}{7}}$ & 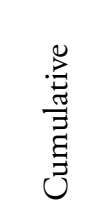 & \\
\hline Yes & 26 & $52 \%$ & $54 \%$ & $54 \%$ & $\begin{array}{c}\text { Recycling }(35 \%) \\
\text { Resource circulation }(23.5 \%) \\
\text { Cooperation }(23.5 \%) \\
\text { Exchange of information and circulation of } \\
\text { flows between organizations }(18 \%)\end{array}$ \\
\hline No & 22 & $44 \%$ & $46 \%$ & $100 \%$ & \\
\hline Total & 48 & $96 \%$ & $100 \%$ & & \\
\hline
\end{tabular}

We found that $54 \%$ of the responding organizations are acquainted with industrial symbiosis on a theoretical level, while the other $46 \%$ did not know the term. The interpretation of the term from organizations which are acquainted with industrial symbiosis were coded and classified into four categories. For the largest portion of organizations, industrial symbiosis represents recycling (35\%), $23.5 \%$ see it as a circulation of resources and the same percent see it as cooperation, while $18 \%$ interpret industrial symbiosis as the exchange of information and circulation of flows between the organizations involved. Further analysis showed that the results of this question come very close to Chertow's (2007) definition of industrial symbiosis with the exception of Chertow's (2000) heuristic rule which states that industrial symbiosis must involve cooperation between three or more organizations.

In relation to the second research question (RQ2), we were interested in the following: Does industrial symbiosis exist between industrial and non-industrial waste management organizations in Slovenia? In this section we asked the organizations which are acquainted with the term industrial symbiosis whether they also implement industrial symbiosis in practice and, if yes, in what way. We were specifically asking about the form of industrial symbiosis implementation - was is it buying or selling waste to be used as raw material, donating waste, mutual exchange of waste, etc. Table 3 contains the number of organizations (including their primary activity) acquainted with the term industrial symbiosis, and which also implement industrial symbiosis in practice. 
Table 3. Contingency table: implementation of industrial symbiosis, primary activity of organizations

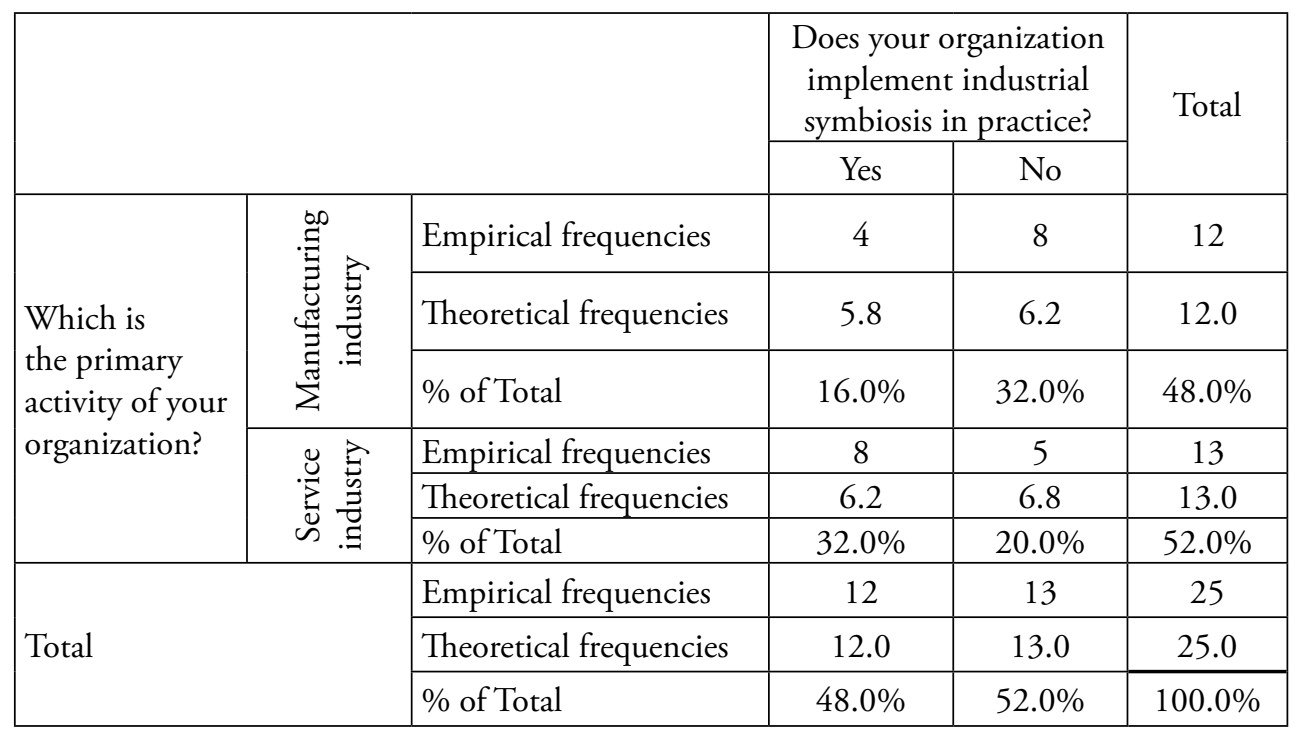

Out of 26 organizations stating that they are acquainted with industrial symbiosis on a theoretical level, only 12 organizations implemented industrial symbiosis in practice, which represented $24 \%$ of all responding organizations, and $48 \%$ of the organizations as being acquainted with the term. Of the organizations implementing industrial symbiosis in practice, eight came from the service industry, while four were primarily manufacturing organizations. Of the responding organizations, 19\% implemented industrial symbiosis in the form of selling waste to be used as raw material; the same share (19\%) of organizations processed waste to be used as raw material; $15 \%$ of organizations donated waste to be used as raw material; $11 \%$ either purchased or exchanged waste or provided business solutions; and $4 \%$ purchased business solutions. Based on this information, we wanted to verify the potential association between the organization's primary activity and its involvement in / implementation of industrial symbiosis using Pearson's Chi-squared test. The condition for using this test was fulfilled - the expected frequencies were 5 or more (Hinton and McMurray, 2017) (Table 4). The results of Pearson's Chi-squared test are shown in Table 4.

Table 4. Pearson's Chi-squared test results

\begin{tabular}{|l|c|c|c|}
\hline & Value & df & Asymp. Sig. (2-sided) \\
\hline Pearson Chi-Square & $1.989^{\mathrm{a}}$ & 1 & .158 \\
\hline N of Valid Cases & 25 & & \\
\hline
\end{tabular}

a. 0 cells $(.0 \%)$ have expected count less than 5 . The minimum expected count is 5.76 
The value of Pearson's Chi-squared test is 1.989 , which is non-statistically significant, as the asymptotic 2 -sided significance value is 0.158 . The results showed that the variables are not associated; therefore we assumed that the primary activity of an organization is not associated with the organization's decision to become involved in or implement industrial symbiosis. Next, we searched for a potential relationship between the operating scope of organizations and their implementation of industrial symbiosis. For this purpose, organizations were classified into four categories based on whether they operated on local, regional, national or international levels - this question allowed for multiple choices. Due to the small sample size of organizations implementing industrial symbiosis and a too comprehensive classification of their operating scope, the condition for using Pearson's Chi-squared test was not fulfilled $-75 \%$ of expected frequencies were below 5. In this case, not even the milder condition for using Pearson's Chi-squared test was fulfilled, where $20 \%$ of expected frequencies are allowed to be under 5 (Hinton and McMurray, 2017).

The comprehensive number of categories also prevented us from using Fisher's exact test to identify potential dependency, for which IBM SPSS, 23.0 statistical software requires a 2-by-2 table, whereas our table size was 4-by-2 (Field, 2016). To fulfill at least one of the conditions, we combined similar categories: local and regional levels were combined with the national level into one category, and the international level represented the second category. Table 5 contains information on the operating scope of the organizations and their involvement in industrial symbiosis.

Table 5. Contingency table: implementation of industrial symbiosis, operating scope

\begin{tabular}{|c|c|c|c|c|c|}
\hline & & & \multicolumn{2}{|c|}{$\begin{array}{c}\text { Does your organization } \\
\text { implement industrial symbiosis? }\end{array}$} & \multirow[t]{2}{*}{ Total } \\
\hline & & & Yes & No & \\
\hline \multirow{6}{*}{$\begin{array}{l}\text { What is the } \\
\text { operating } \\
\text { scope of your } \\
\text { organization? } \\
\text { Multiple } \\
\text { choices allowed. }\end{array}$} & \multirow{3}{*}{ 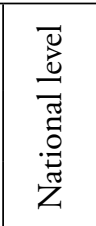 } & Empirical frequencies & 10 & 8 & 18 \\
\hline & & Theoretical frequencies & 8.7 & 9.3 & 18.0 \\
\hline & & $\%$ of Total & $18.7 \%$ & $17.3 \%$ & $36 \%$ \\
\hline & \multirow{3}{*}{ 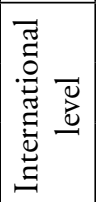 } & Empirical frequencies & 6 & 9 & 15 \\
\hline & & Theoretical frequencies & 7.3 & 7.7 & 15.0 \\
\hline & & $\%$ of Total & $13.3 \%$ & $16.7 \%$ & $30 \%$ \\
\hline \multirow{3}{*}{\multicolumn{2}{|c|}{ Total }} & Empirical frequencies & 16 & 17 & 33 \\
\hline & & Theoretical frequencies & 16.0 & 17.0 & 33.0 \\
\hline & & $\%$ of Total & $32 \%$ & $34 \%$ & $66 \%$ \\
\hline
\end{tabular}


Of the responding organizations, 10 organizations selected the national level as the scope of operation, six organizations selected only the international level, while four selected both the national and international operating scope. We used this information to verify the potential dependency between the operating scope of the organizations and their involvement in industrial symbiosis. After combining the operating scope categories, the conditions for using Pearson's Chi-squared test were fulfilled - the expected frequencies were 5 or more (Table 6).

Table 6. Pearson's Chi-squared test results

\begin{tabular}{|l|c|c|c|}
\hline & Value & df & Asymp. Sig. (2-sided) \\
\hline Pearson Chi-Square & $0.793^{\mathrm{a}}$ & 1 & .373 \\
\hline N of Valid Cases & 33 & & \\
\hline
\end{tabular}

a. 0 cells $(.0 \%)$ have expected count less than 5 . The minimum expected count is 7.27

The value of Pearson's Chi-squared test is 0.793 , which makes it non-statistically significant - the value of asymptotic 2 -sided significance is 0.373 . This result indicated that the variables are not associated, i.e. an organization's scope of operation is not relevant in terms of its involvement in industrial symbiosis.

The third research question (RQ3) inquired: Which are the main reasons for organizations to cooperate in industrial symbiosis? We assumed that the main reason for organizations implementing industrial symbiosis was either EU environmental legislation, which is becoming more rigorous with time; social responsibility as a socio-cultural factor; or the environmental, economic and social benefits of industrial symbiosis. The reasons for organizations to become involved in industrial symbiosis and their prevalence are displayed in Table 7.

Table 7. Crosstabulation: main reasons for organizations to cooperate in industrial symbiosis, operating scope of organizations

\begin{tabular}{|l|l|c|c|c|c|c|c|}
\hline \multicolumn{2}{|c|}{} & \multicolumn{3}{|c|}{$\begin{array}{c}\text { Which are the main reasons for your organization to cooperate } \\
\text { in industrial symbiosis? Multiple choices possible. }\end{array}$} \\
\cline { 3 - 9 } & $\begin{array}{c}\text { Increasingly } \\
\text { strict EU } \\
\text { environmental } \\
\text { legislation }\end{array}$ & $\begin{array}{c}\text { Social } \\
\text { responsi- } \\
\text { bility }\end{array}$ & $\begin{array}{c}\text { Environ- } \\
\text { mental } \\
\text { benefits }\end{array}$ & $\begin{array}{c}\text { Economic } \\
\text { benefits }\end{array}$ & $\begin{array}{c}\text { Social } \\
\text { benefits }\end{array}$ & Total \\
\hline $\begin{array}{l}\text { What is the } \\
\text { operating } \\
\text { scope of your } \\
\text { organization? } \\
\text { Multiple } \\
\text { choices } \\
\text { allowed. }\end{array}$ & Local level & 1 & 1 & 1 & 1 & 0 & 4 \\
\cline { 2 - 9 } & Regional level & 2 & 2 & 2 & 2 & 1 & 9 \\
\cline { 2 - 9 } & National level & 6 & 6 & 7 & 7 & 2 & 16 \\
\hline
\end{tabular}


Of the 49 organizations with a diverse scope of operation, meaning they operate on several levels at the same time, 12 organizations implemented industrial symbiosis. As can be seen from Table 7, social responsibility was selected as the most frequent reason for participating in industrial symbiosis. This mostly applied to organizations operating on national and international levels. For organizations operating on the national level, environmental and economic benefits and the increasingly strict EU environmental legislation were also among the top reasons. This result did not come as a surprise to us, because social responsibility has become an important socio-cultural factor in today's economy in terms of creating a competitive advantage, maintaining one's reputation, and building trust among organizations. Thus, this result was expected, especially for organizations with an international scope of operation. However, it was not possible to identify the association between an organization's scope of operation and its main reasons for participating in industrial symbiosis. The basic or milder condition for using Pearson's Chi-squared test (96\% of expected frequencies under 5) was not fulfilled. At the same time, we were unable to combine categories in order to use the Chi-squared test. In order to use Fisher's exact test in IBM SPSS, 23.0 software interface, we needed a smaller number of categories: instead of a 4-by-5 table, we needed a 2-by-2 table. Therefore, we used the RStudio software interface which allowed us to verify the variable dependency in a 4-by-5 table using Fisher's exact test (Field et al., 2012). The results of this test are shown in Table 8.

Table 8. Results of Fisher's exact test

\begin{tabular}{|l|c|c|}
\hline & p-value & Altern. Hyp. \\
\hline $\begin{array}{l}\text { Fisher's Exact Test for Count Data with simulated p-value } \\
\text { (based on } 1000 \text { replicates) }\end{array}$ & 1 & 2-sided \\
\hline N of Valid Cases & 32 & \\
\hline
\end{tabular}

The p-value in Fisher's exact test is 1, which is non-statistically significant, because it exceeds 0.05 . The results indicated that the variables are not associated, which implies that the main reasons for participating in industrial symbiosis are not associated to an organization's scope of operation.

In the fourth research question (RQ4): Is industrial symbiosis implemented in the form of (informal) industrial symbiosis networks between three or more organizations? we were asking about the number of organizations involved in industrial symbiosis and the size of individual industrial symbiosis networks comprised of responding organizations from the effective research sample. As a follow-up question, we also wished to identify the organization types of members of the industrial symbiosis network.

From Table 9 it is evident that organizations, notwithstanding their size, equally cooperated with different organizations, although cooperation with legal entities and national agencies was prevalent. As in the analysis of the previous research question, we were unable to verify the potential association between the type of organizations involved in industrial symbiosis and the size of organization. 
Table 9. Crosstabulation: partners to organizations in implementation of industrial symbiosis, size of organization

\begin{tabular}{|c|c|c|c|c|c|c|c|}
\hline & \multicolumn{7}{|c|}{$\begin{array}{c}\text { Which type of organizations in Slovenia do you cooperate with } \\
\text { Multiple choices allowed. }\end{array}$} \\
\hline $\begin{array}{l}\text { How many people work } \\
\text { at your organization? } \\
\text { Multiple choices } \\
\text { allowed. }\end{array}$ & 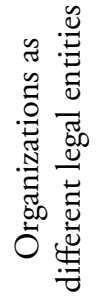 & 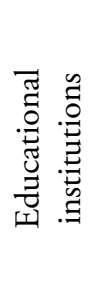 & 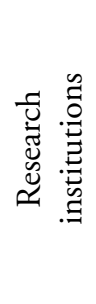 & 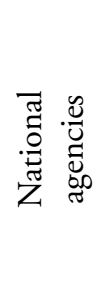 & 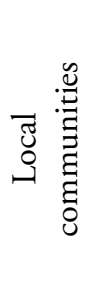 & $\sum_{i}^{\stackrel{\pi}{\tilde{g}}}$ & 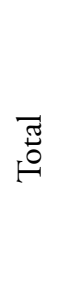 \\
\hline $1-50$ & 4 & 2 & 2 & 2 & 3 & 2 & 15 \\
\hline More than 50 & 5 & 4 & 4 & 5 & 4 & 4 & 26 \\
\hline Total & 9 & 6 & 6 & 7 & 7 & 6 & 41 \\
\hline
\end{tabular}

The precondition for using the Chi-squared test was not fulfilled: $73 \%$ of expected frequencies were under 5. The alternative strategy of combining categories in order to allow for the Chi-squared test was also not possible in this case. Numerous categories were also the reason we were unable to use Fisher's exact test: the table was sized 2-by-6 instead of 2-by-2, which is the required dimension of tables to be used in Fisher's exact test in IBM SPSS 23.0 software. Again, we tested the variable associations in the RStudio software using Fisher's exact test (Table 10).

Table 10. Results of Fisher's exact test

\begin{tabular}{|l|c|c|}
\hline & Value & Asymp. Sig. (2-sided) \\
\hline Fisher's Exact Test & & .994 \\
\hline N of Valid Cases & 41 & \\
\hline
\end{tabular}

As can be seen, the p-value in Fisher's exact test is 0.994 , which is non-statistically significant, because it exceeds 0.05 . The results indicated that the variables are not associated, which implies that the type of organizations they partner with in the implementation of industrial symbiosis is not related to the size of an organization. Next, we were interested in the size of industrial symbiosis networks - those involving the organizations participating in our research.

We categorized expected industrial symbiosis networks as either small (containing some 10 nodes / organizations), medium (containing some 100 organizations), or large (containing some 1000 organizations), and calculated the number of individual organization types participating in these networks (Table 11). 
Table 11. Crosstabulation: number of organizations involved in industrial symbiosis networks, type of organization / stakeholder

\begin{tabular}{|c|c|c|c|c|c|c|c|c|}
\hline \multirow[b]{2}{*}{$\begin{array}{l}\text { Which of these organizations do you } \\
\text { cooperate with in Slovenia? }\end{array}$} & \multicolumn{8}{|c|}{$\begin{array}{l}\text { How many organizations of individual type are } \\
\text { involved in implementation of industrial symbiosis? }\end{array}$} \\
\hline & $\begin{array}{c}1 \\
\text { to } \\
5\end{array}$ & $\begin{array}{c}5 \\
\text { to } \\
10\end{array}$ & $\begin{array}{l}10 \\
\text { to } \\
15\end{array}$ & $\begin{array}{l}15 \\
\text { to } \\
20\end{array}$ & $\begin{array}{l}\text { More } \\
\text { than } \\
20\end{array}$ & $\stackrel{\text { 퓸 }}{\circ}$ & $\frac{. \bar{\sigma}}{>\pi}$ & 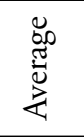 \\
\hline Organizations as different legal entities & 2 & 4 & 0 & 0 & 3 & 9 & 9 & 2.8 \\
\hline $\begin{array}{l}\text { Educational } \\
\text { institutions (school, faculty, university) }\end{array}$ & 3 & 0 & 0 & 0 & 3 & 6 & 6 & 3.0 \\
\hline $\begin{array}{l}\text { Research } \\
\text { institutions (technological park, } \\
\text { laboratory) }\end{array}$ & 4 & 1 & 1 & 0 & 0 & 6 & 6 & 1.5 \\
\hline $\begin{array}{l}\text { National agencies (ministry, } \\
\text { government agency) }\end{array}$ & 6 & 0 & 0 & 0 & 1 & 7 & 7 & 1.6 \\
\hline Local community & 3 & 0 & 0 & 1 & 3 & 7 & 7 & 3.1 \\
\hline Media & 4 & 2 & 0 & 0 & 0 & 6 & 6 & 1.3 \\
\hline Total & 22 & 7 & 1 & 1 & 9 & 41 & 41 & \\
\hline
\end{tabular}

We found that we were dealing with small - even micro to be precise - industrial symbiosis networks containing either up to five or five to 10 organizations. In these networks, organizations predominantly cooperate with national agencies, tightly followed by research institutions and the media. When organizations cooperate with several types of organizations, $45 \%$ of networks involving organizations of different legal entities contain five to 10 organizations; $50 \%$ of networks involving educational institutions contain one to five organizations whereas the other $50 \%$ of these networks contain more than 20 organizations; $67 \%$ of networks involving research institutions contain one to five organizations; $86 \%$ of networks involving national agencies contain one to five organizations; $43 \%$ of networks involving local communities contain one to five organizations, whereas another $43 \%$ of these networks contain more than 20 organizations; and $67 \%$ of networks involving the media contain one to five organizations.

In the last research question (RQ5), we asked participating organizations the following question: Do waste management organizations feel that an online platform to simplify their search for potential partners in industrial symbiosis is needed? With this question we were looking to ascertain whether organizations would choose to sell or buy waste as raw materials and related supporting services through an online platform that would allow such exchange. The results showed that $98 \%$ of Slovenian organizations ( 49 out of 50, $\mathrm{N}=50$ ) participating in the questionnaire would have used an online platform for their implementation of industrial symbiosis, if such a platform existed. We then asked these organizations why they would have chosen to use the online platform. Most $(37.5 \%)$ 
would have used the online platform for its many advantages: to close material flows in the most economically and environmentally friendly way, to gain an overview of waste, and to speed up the process of supply and demand. Of the organizations that would have used the online platform, $31 \%$ would have used it for cooperation, $19 \%$ for the purpose of re-using waste, and $12.5 \%$ for financial benefits. To continue, we asked organizations - both those not yet implementing industrial symbiosis and those that already have - whether they would prefer to have such online platform available (Table 12).

Table 12. Crosstabulation: involvement of organizations in industrial symbiosis, organizations interested in online industrial symbiosis platform

\begin{tabular}{|l|c|c|c|c|c|}
\hline \multicolumn{2}{|c|}{} & \multicolumn{2}{|c|}{$\begin{array}{c}\text { If an online platform for implementation } \\
\text { of industrial symbiosis in Slovenia was } \\
\text { available, would you have used it for } \\
\text { implementation of industrial symbiosis? }\end{array}$} & \multirow{2}{*}{ Total } \\
\cline { 3 - 5 } & Yes & No & Missing & \\
\hline $\begin{array}{l}\text { Does your organization } \\
\text { implement industrial } \\
\text { symbiosis? }\end{array}$ & Yes & 9 & 0 & 3 & 12 \\
\cline { 2 - 6 } & No & 10 & 1 & 2 & 13 \\
\hline Total & & 19 & 1 & 5 & 25 \\
\hline
\end{tabular}

The results show that nine out of 12 organizations already implementing industrial symbiosis would have used the online platform for industrial symbiosis. The same applies to 10 organizations which were not implementing industrial symbiosis at the time of our research. Out of 25 organizations which answered these two questions, 19 organizations would have decided to implement industrial symbiosis using an online platform. Once again, we were interested in the potential association between the variables - does an organization's involvement in industrial symbiosis imply their deciding on whether to use an online industrial symbiosis platform for implementation of industrial symbiosis. The basic or milder condition for using the Chi-squared test was not fulfilled: $66.7 \%$ of expected frequencies were under 5 . We were also unable to combine categories in order to allow for the Chi-squared test. As a result, we used Fisher's exact test to check for a potential association between the variables. Since the table size was 2-by-2, we were able to perform the test in IBM SPSS 23.0 software (Table 13).

Table 13. Results of Fisher's exact test

\begin{tabular}{|l|c|c|}
\hline & Value & Asymp. Sig. (2-sided) \\
\hline Fisher's Exact Test & 1.221 & 1.000 \\
\hline N of Valid Cases & 25 & \\
\hline
\end{tabular}

The test p-value is 1.221 , which makes it non-statistically significant as it is below 0.05 . Although these variables were presumed as having the highest rate of dependence before 
the beginning of the research, we found that they were not associated at all. This implies that an organization's involvement in industrial symbiosis was not associated with their decision to use an industrial symbiosis online platform for implementation of industrial symbiosis.

For all cases where the variable association test resulted in a variable that was not associated, we assumed that this was caused by respondents not answering all the questions in the questionnaire. As previously mentioned, 13 respondents did not complete the questionnaire process while 37 respondents finished the questionnaire process; however some of these 37 had not answered all the questions. We believe that it would have been possible to identify association in at least one of the cases above, if all 50 respondents had answered all the questions in the questionnaire.

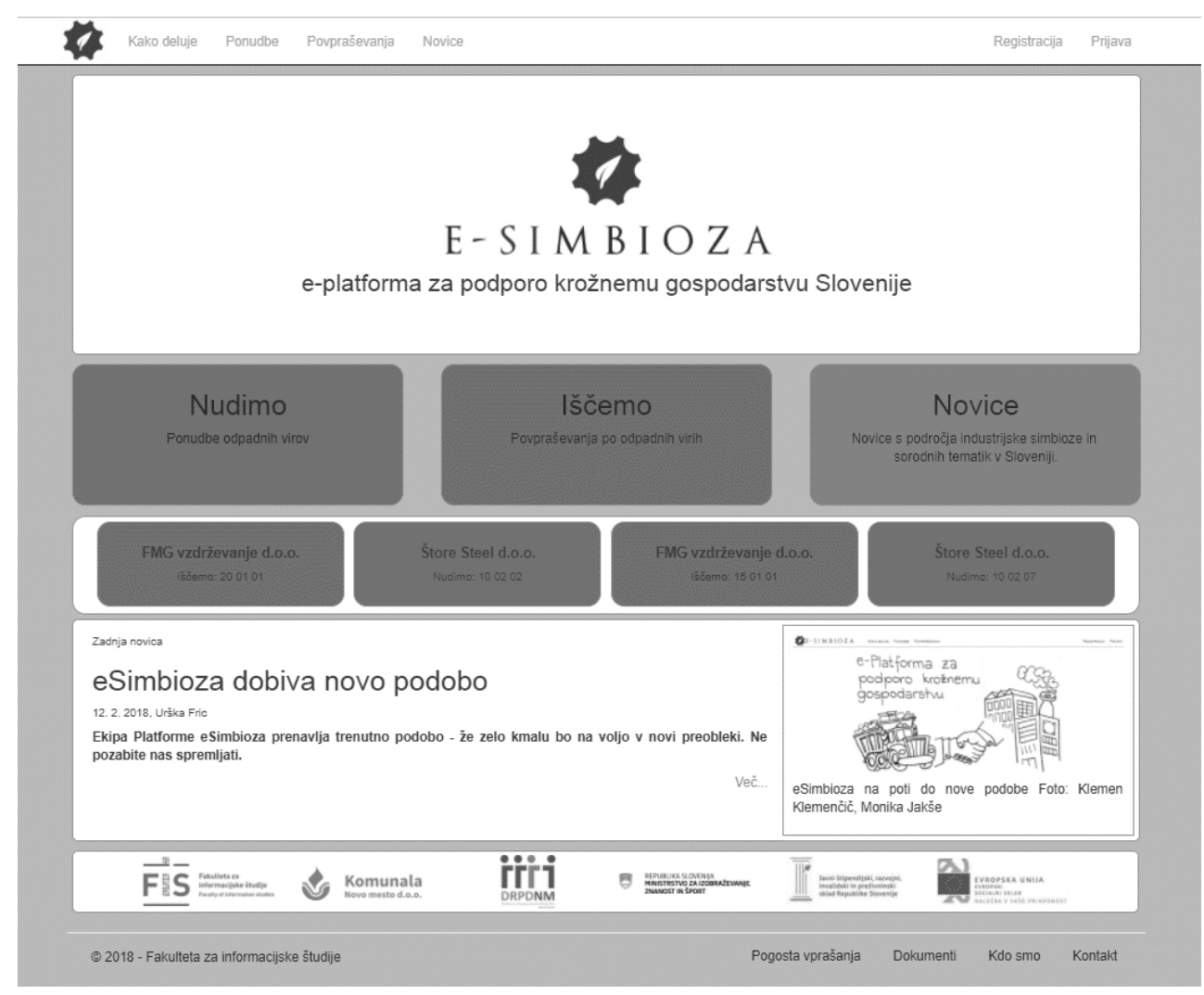

Picture 1. E-Simbioza cover page

Finally, the responding organizations were asked to identify the type of waste they were interested in buying or selling. This information was used as input data when setting up the online platform. We also asked them to enter the quantity and unit, time availability of this quantity, name of organization, location, contact person, email address, and the purpose of use. The information was entered into the initial database. Out of 50 orga- 
nizations, 17 entered complete information regarding selling waste, and nine entered complete information regarding buying waste. Using Microsoft Asp.NET and database, we then set up and published the e-Simbioza online platform, which is available freeof-charge (Faculty of Information Studies in Novo mesto, 2017). The e-Simbioza cover page is shown in Picture 1.

With the "less is more" user experience principle in mind, we wanted to create a userfriendly and simple e-platform and, by doing so, entice the interest of potential industrial symbiosis organizations. E-Simbioza is the first and only online platform in Slovenia which enables sending buying and selling requests and reviewing these requests. Buyers, intermediaries and sellers of waste are now able to establish contact and cooperation. At the same time, the online platform allows them to buy and sell related logistics services with key services involving waste processing and transport between organizations. According to the List of Waste, 18 organizations from the manufacturing or service industry are currently looking for eight and offering 34 different types of waste. The significance of the e-Simbioza platform is seen in the synergies created between organizations, where one organization's non-hazardous waste material has become another organization's raw material. To date, four participating organizations in e-Simbioza have begun building synergies.

\section{CONCLUSION}

For organizations that performed industrial symbiosis or its similar forms on a "oneon-one" basis until 2017, the e-Simbioza online platform could represent a major step forward in terms of practicing and developing industrial symbiosis. Our research points to the conclusion that the e-Simbioza platform is a very useful tool for motivated organizations. ${ }^{5}$ In order to enhance the establishment of industrial symbiosis networks, e-Simbioza publicly displays all organizations involved in web-based waste exchange as suppliers, intermediaries, or buyers. Public debates, numerous events of organizations (national agencies, different commercial legal entities, educational and research institutions etc.), new projects and also dedicated implementation of all EU measures and directives in Slovenia show the level of interest and commitment to transform from a conventional linear economy to a circular economy.

We expect the volume of waste at Slovenian waste disposal facilities to be reduced and the continued development of e-Simbioza could be one of the main tools of this process. Forthcoming functionalities that will provide even better and more detailed information on the supply and demand for different types of waste will further enhance "carrots" in the form of increasing the number of commercial transactions. Economic benefits will extend to intermediaries dealing with logistics support for everyone involved in indus-

5 This is also exemplified by the continued development and use of the e-Simbioza platform by most of the organizations that participated in our sample since the conclusion of the initial project. 
trial symbiosis networks. As a result, e-Simbioza could contribute substantially to environmental benefits, and conservation of the natural environment. Despite our positive reinforcement, we are aware that it was not possible to decrease emissions originating at Slovenian landfills by the time e-Simbioza was published; however, by continuing the promotion of industrial symbiosis through e-Simbioza we can prevent future negative impacts on the environment caused by landfill waste that can be reused once or several times.

In the near future, we aim to develop an increasingly comprehensive, multi-functional, integrated e-platform that will promote, demonstrate and advance industrial symbiosis in European countries while focusing on facilitating the continuous and sustainable exchange and cooperation in the creation of knowledge between the business community, research and higher-education institutions. The functionality of this e-platform will include formulation of innovative short educational modules which will enable organizations to engage in the creation of new networks adjustable to the needs of large organizations and SMEs; inclusion of new technologies, i.e. semantic web, networking, computer modelling and simulations of networks, implemented with high-performance computing, to better promote IS on a wider scale. Therefore, this e-platform will provide opportunities for innovative and multidisciplinary approaches to education and research.

We will use the competencies of higher education institutions (HEIs) to recognize, appreciate, and analyze real-life socio-ecological problems that innovative enterprises, particularly SMEs, are dealing with to achieve sustainable competitiveness. This will facilitate the exchange, flow and co-creation of knowledge between HEIs and enterprises and will increase innovation capability and capacity in both HEIs and enterprises. Codesigning the e-platform will make HEIs and enterprises more aware of mutual benefits of cooperation. The e-platform strategic dialogue methodology will contribute to improving the innovation capability and capacity of European regions through fostering innovation in HEIs and enterprises. Staff training will stimulate their entrepreneurship and entrepreneurial skills and contribute to HEIs being more responsive and relevant to organization needs. The strategic dialogue will facilitate the exchange, flow and cocreation of knowledge and co-designing of future innovative socio-ecological solutions.

\section{REFERENCES}

ARSO - Slovenian Environment Agency. (2017). Environmental protection. URL: http://www.arso.gov.si/en/environmental\%20protection/ (November 17, 2017).

Blaxter, L., Hughes, C. and Tight, M. (1996). How to research? Buckingham, PI: Open University Press.

Boshkoska, B., Rončević, B., Džajić and Urš̌čc, E. (2018). Modeling and Evaluation of the Possibilities of Forming a Regional Industrial Symbiosis Networks. Social Sciences, 7(1): 2-26. 
Chertow, M. R. (2000). Industrial Symbiosis: Literature and Taxonomy. Annual Review of Energy and the Environment, 25: 313-337.

Chertow, M. R. (2007). Uncovering Industrial Symbiosis. Journal of Industrial Ecology, 11(1): 11-26.

Chertow, M. R. and Lombardi, R. (2005). Quantifying Economic and Environmental Benefits of Co-located Firms. Environmental science and technology, 39(17): 6535-6541.

Deutz, P. (2014). Food for Thought: Seeking the Essence of Industrial Symbiosis. In: Salomone R. and Saija, G. (eds.), Pathways to Environmental Sustainability Methodologies and Experiences (pp. 3-11). Springer: Switzerland.

Domenech Aparisi, T. A. (2010). Social Aspects of Industrial Symbiosis Networks. Ph.D. Dissertation. London: Barlett School of Graduate Studies, University College London. URL: http://discovery.ucl.ac.uk/762629/ (December 4, 2017).

Ellen MacArthur Foundation. (2017). Circular Economy Overview. URL: https://www. ellenmacarthurfoundation.org/circular-economy/overview/concept(December 2, 2017).

European Commision. (2014). Communication from the Commission to the European Parliament, the Council, the European Economic and social Committee and the Committee of the Regions. Towards a circular economy: A zero waste programme for Europe. Brussels, 7 July 2014, COM(2014) 398 final. URL: https:// eur-lex.europa.eu/resource.html?uri=cellar:50edd1fd-01ec-11e4-831 f-01aa75ed71a1.0001.01/DOC_1\&format=PDF (November 16, 2017).

European Parliament and Council (2008). Directive 2008/98/EC of the European Parliament and of the Council of 19 November 2008 on waste and repealing certain Directives. Official Journal of the European Union, L312: 3-30. URL: http://eurlex.europa.eu/legal-content/EN/TXT/PDF/?uri=CELEX:32008L0098\&from= EN (November 16, 2017).

Ehrenfeld, J. and Gertler, N. (1997). Industrial Ecology in Practice: The Evolution of Interdependence at Kalundborg. Journal of Industrial Ecology, 1(1): 67-80.

Faculty of Information Studies in Novo mesto. (2017). E-Simbioza platform. URL: http://esimbioza.fis.unm.si/ (November 16, 2017)

Field, A. (2016). Discovering Statistics using IBM SPSS Statistics. London, New Delhi, Singapore, Washington DC: SAGE.

Field, A., Miles, J. and Field, Z. (2012). Discovering Statistics using R. London: SAGE. Fric, U. (2017). Ekološke, ekonomske i društvene koristi izvođenja industrijske simbioze. In: Matešić, M. (ed.), Zbornik radova 9. Konferencije o društveno odgovornom poslovanju - DOP (pp. 93-108). Zagreb: Hrvatski poslovni savjet za održivi razvoj.

Hinton, P. R. and McMurray, I. (2017). Presenting Your Data with SPSS Explained. London, New York: Routledge.

Lombardi, D. R. and Laybourn, P. (2012). Redefining Industrial Symbiosis, Crossing Academic-Practitioner Boundaries. Journal of Industrial Ecology, 16(1): 28-37. 
Manahan, S. E. (1999). Industrial Ecology: Environmental Chemistry and Hazardous Waste. Boca Raton, FL: CRC Press.

Mirata, M. and Emtairah, T. (2005). Industrial Symbiosis Networks and the Contribution to Environmental Innovation: The Case of Landskrona Industrial Symbiosis Programme. Journal of Cleaner Production, 13: 993-1002.

Business directory bizi.si. (2017). Iskanje. URL: https://www.bizi.si/ (November 17, 2017).

Rončević, B. and Fric, U. (2015). Researching Industrial Symbiosis: Challenges and Dilemmas. In: Povh, J. (ed.), Applied Moddeling and Computing in Social Science (pp. 35-50). Frankfurt am Main: Peter Lang.

SURS - Statistical Office of the Republic of Slovenia (2017). Environment. URL: http://pxweb.stat.si/pxweb/Dialog/viewplus.asp?ma=H003S\&ti=\&path=../Database/Hitre_Repozitorij/\&lang=2 (December 22, 2017). 


\title{
E-SIMBIOZA KAO PUT PREMA KRUŽNOJ EKONOMIJI KROZ INDUSTRIJSKU SIMBIOZU U SLOVENIJI
}

\author{
Urška Fric i Borut Rončević
}

\begin{abstract}
Sažetak
U članku se po prvi put analizira upoznatost s idejom industrijske simbioze (IS) u Sloveniji kao i njena implementacija. Podaci su dobiveni online anketom provedenom na manjem uzorku organizacija koje su aktivno uključene u upravljanje otpadom. Dobiveni rezultati pokazuju da su ove organizacije motivirane primjenjivati industrijsku simbiozu, a njihovi razlozi uključuju okolišne i ekonomske prednosti njene primjene, kao i pitanja drustvene odgovornosti. Mecutim, vidljivo je da čak ni ove organizacije nisu sasvim upoznate s idejom industrijske simbioze kao ni njenom primjenom. Organizacijama koje primjenjuju industrijsku simbiozu bili bi korisni online alati koji bi im omogućili lakši pronalazak potencijalno zainteresiranih aktera sodredenim vrstama otpada za razmjenu. Veličina uzorka ne omogućuje poopćavanje rezultata, no istraživanje daje naznake da bi uspostava online platforme koja promiče industrijsku simbiozu značajno doprinijela pozitivnom pomaku prema kružnoj ekonomiji. U članku je predstavljen primjer jedne takve uspješne inicijative - e-Simbioza - pa se raspravlja i o mogućnostima njenog budućeg razvoja.
\end{abstract}

Ključne riječi: kružna ekonomija, industrijska simbioza, mreže industrijske simbioze, e-platforma, suradnja

\section{E-SIMBIOZA ALS EIN WEG ZUR KREISLAUFWIRTSCHAFT DURCH DIE INDUSTRIELLE SYMBIOSE IN SLOWENIEN}

\author{
Urška Fric und Borut Rončević
}

\begin{abstract}
Zusammenfassung
Im Artikel wird zum ersten Mal der Bekanntheitsgrad der Idee der industriellen Symbiose (IS) in Slowenien, sowie deren Implementierung analysiert. Die Angaben stammen aus einer Onlineumfrage, die an einem kleineren Muster von am Abfallmanagement aktiv beteiligten Organisationen durchgeführt wurde. Die Egebnisse zeigen, dass diese Organisationen dazu motiviert sind, die industrielle Symbiose anzuwenden, ihre Gründe dafür schließen ökologische und ökonomische Vorteile deren Anwendung, sowie die Fragen der gesellschaftlichen Verantwortung ein. Es ist jedoch sichtbar, dass sogar diese Organisationen nicht völlig mit der Idee der industriellen Symbiose und deren Anwendung vertraut sind. Für die Organisationen, die die industrielle Symbiose anwenden, wären Onlinewerkzeuge nützlich, die ihnen ermöglichen würden, potentielle Interessenten mit bestimmten Abfallarten für den Tausch zu finden. Die Größe des Musters ermöglicht nicht, dass die Ergebnisse verallgemeinert werden, die Forschung jedoch liefert Anzeichen dafür, dass die Erstellung einer Onlineplattform, die die industrielle Symbiose vorantreibt, einer positiven Annäherung an die Kreislaufwirtschaft wesentlich beitragen würde. Im Artikel wird das Beispiel solch einer erfolgreichen Initiative - e-Simbioza - angeführt und die Möglichkeiten ihrer zukünftigen Entwicklung werden erörtert.
\end{abstract}

Schlüsselwörter: Kreislaufwirtschaft, industrielle Symbiose, Netze der industriellen Symbiose, e-Plattform, Zusammenarbeit 